\title{
Commodity Derivative Transaction Comparability: Evidence From South Africa
}

Sanlie L Middelberg, North-West University, South Africa

Pieter W Buys, North-West University, South Africa

\begin{abstract}
Financial statements are used by investors and financiers in their investment or financing decisions. The accounting treatment of individual transactions is reflected in the annual financial statements; therefore, similar transactions should be accounted for similarly by organisations in the same industry, otherwise these financial statements become incomparable. Commodity derivatives are utilised extensively by agricultural companies and processors in their risk management strategies. The accounting standard, IAS 39, on financial instruments such as commodity derivatives should be interpreted and applied consistently in order to ensure comparability of financial statements. Within the South African agricultural companies and processors context, this paper identified and considered eight basic transactions commonly used when buying and selling grain. It was found that there is not always a consistent accounting treatment of these transactions among industry players and therefore a best practice methodology for interpreting and applying the accounting standard was formulated for each of the eight transaction types.
\end{abstract}

Keywords: Commodity Derivative Transactions; Commodity Derivative Comparability, IAS 39; South African Agriculture

\section{INTRODUCTION}

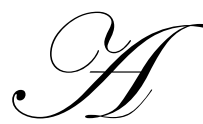

key aim of financial reporting is the provision of financial information regarding the organisation in support of decision-making (Cronje, 2010; Williams, 2009; Buys, 2008; Sundem, 2007). Furthermore, the users of financial statements, such as financiers, analysts and investors, need comparable information (Rossouw, 2010). Since the recordings of the organisations' individual transactions are collated to form the basis of the annual financial statements, the accounting treatment of similar transactions should therefore be similar. If not, these financial statements may become incomparable.

Due to rising food prices and a concern over food security in coming years (Dunne \& Jenkins, 2008; Nair, 2008), it is imperative to ensure that the overall agricultural sector in South Africa is functioning optimally. This, in turn, will require strong agricultural companies supporting the agricultural sector in providing services to producers and processors (Maier et al., 2009). Since commodity derivative contracts form a major part of the business operations of South African agricultural companies and processors in its capacity of offering protection against commodity price fluctuations, the accounting treatment of the transactions containing these contracts should be consistent between agricultural companies and processors.

The aim of this paper is to identify similar transactions in respect of commodity derivatives, as found in South African agricultural companies and processors, and to formulate a best practices standard methodology to account for each transaction. A standard methodology will lead to more comparable financial statements and will lead to better informed decision-making by financiers, investors and analysts. 


\section{PROBLEM STATEMENT AND RESEARCH OBJECTIVE}

When considering the accounting treatment of commodity derivative contracts, the International Accounting Standard (IAS) 39 addresses the recognition and measurement of financial instruments, such as derivatives. IAS 39 is accompanied by i) the basis of conclusions that summarises the IASB's considerations in reaching the conclusions thereon (IASB, 2008:2091-2174), ii) an illustrative example (IASB, 2008:2175-2183), and iii) a guidance on implementation (IASB, 2008:2184-2297). However, when considering the complexity of this subject matter, these appendixes may not be sufficient when interpreting and implementing the relevant accounting standards. Furthermore, no completed research on commodity derivative contracts and the accounting treatment thereof in South African agricultural companies and processors in support of derivative contract applications could be found.

Set against the background of the aforementioned, the primary research problem for purposes of this article can be defined as follows:

$\boldsymbol{P}_{1}$ : How diverse and broad in scope are the commodity derivative types used by the key role-players in the South African agricultural sector?

These research objectives, aiming to address the above problem statements and to fill this knowledge gap, intend to make the following contributions:

- Identifying the primary transaction types in respect of commodity derivative contracts that are specific to South African agricultural companies and processors; and

- $\quad$ Formulating a best practices accounting treatment for each of these transaction types.

\section{RESEARCH DESIGN AND METHODOLOGY}

This research study can be categorised in both the interpretive and functionalist paradigm when considering Burrell and Morgan's 'Four Paradigms of Social Theory' framework (1979). A multi-paradigm approach was therefore followed. The research can further be classified as a descriptive and applied case study. In meeting the set research objectives, a primarily case study-based empirical study was conducted. The empirical study was conducted by using a developed questionnaire completed during structured interviews encompassing respondents from the agricultural sector in South Africa. The empirical study phase consisted of seven case studies from the agricultural sector, which were identified by utilising unrestricted non-probability sampling. The respondents together accounted for approximately $68 \%$ of the total grain handled in the South African agricultural sector. Structured interviews were conducted with key representatives of the respondents. For further interpretation and opinion, the results of the questionnaire and interviews with the respondents were discussed with representatives of the technical departments of three of the 'Big Four' audit firms. Based hereupon, a standardised, Best Practices accounting methodology for each of the transaction types was developed.

The remainder of this article is set out as follows. Firstly, the context with regard to the South African agricultural companies and processors and the accounting treatment of commodity derivatives are provided, which is then followed by the details of the empirical study, including the transactions as found. The article is concluded with a short discussion and some key limiting factors and areas for further research.

\section{THE SOUTH AFRICAN CONTEXT}

The agricultural sector in South Africa plays an important role in providing affordable food to its growing population. Even though agricultural companies are key players offering financing and market advisory services to producers and processor, they also require financing. The 2010 PricewaterhouseCoopers (PwC) benchmarking survey on the performance of agribusinesses in South Africa found that the agribusinesses debtors' books grew substantially and that, in order to finance these debtors' books, additional financing was required (PwC, 2011). According to Van Burick (2008), the director general of agriculture, Njabulo Nduli, stated that producers' access to financing is a major challenge in South African agriculture. This challenge, combined with i) an environment where 
it is perceived that government is not really supporting commercial farming, ii) producers having to compete with government subsidised agricultural producers in developed countries, and iii) high input costs of producers, stresses the fact that strong agricultural companies are essential in providing support to producers in South Africa.

Producers, agricultural companies and processors are subject to commodity price fluctuations. Commodity derivatives are utilised to protect these entities against adverse price fluctuations. In South Africa, such commodity derivatives are primarily traded on the JSE SAFEX. In the opinions of Sir David Tweedie, the chairman of the International Accounting Standards Board (IASB) (Lavin, 2010), the president of the United States of America, Barack Obama (Temkin, 2009) and Trevor Manuel, the head of the South African National Planning Commission (Pickworth, 2009), the accounting treatment of these commodity derivatives can be very intimidating and needs to be clarified and simplified. In line with the important and key objective of accounting and financial statements, a standardised interpretation for the primary transaction types in respect of commodity derivative contracts becomes necessity.

\section{RESULTS AND RECOMMENDATIONS}

During the analysis of the respondents' business operations, eight primary transaction types were identified. However, not all the respondents always offer all eight of these transaction types, and variations of the transactions may also be offered. The transaction types can be divided into two broad types of contracts, namely i) contracts with producers and ii) contracts with processors. The first five transaction types fall within the first broad type, namely contracts with the producers, in which the agricultural companies offer various options to market and sell the producer's grain. These five transaction types are the 1) pre-season fixed-price contract, 2) fixed-price purchase contract, 3) pre-season minimum-price contract, 4) un-priced contract, and 5) delayed-price contract. These options differ based on when the contract is entered into, how the price is determined, when the price is determined and whether additional protection against price fluctuations is required.

Transaction types six to eight, namely the 6) mill-door contract, 7) un-priced delivery contract and 8) priced delivery contract, all fall within the category of contracts with processors. Processors enter into contracts with agricultural companies in order to purchase grain for their normal usage requirements. Based on this distinction between contract categories, each of these eight transaction types will now be discussed, followed by a best-practice recommendation for each.

\section{Contracts with producers}

\section{Transaction type 1: Pre-season fixed-price contract}

The first transaction type identified by the respondents is the pre-season fixed price contract and is entered into by a producer and an agricultural company. A pre-season contract is generally entered into before the commodity's planting season commences. Refer to Figure 1 below for a transaction flow of a pre-season fixed price contract.

A pre-season contract can be split into two further contracts, namely the supply contract with the producer and the SAFEX derivative contract. The supply contract (refer to Step 1 in Figure 1) represents a supply transaction between the producer and the agricultural company where the agricultural company offers a SAFEX-based price for the producer's grain. After the producer harvested his/her crop, it is delivered to the agricultural company at the agreed price within a specified period. The SAFEX derivative contract (refer to Step 2 in Figure 1) represents a SAFEX short position that is entered into by the agricultural company in order to hedge itself against commodity price fluctuations.

After the harvest time, the producer delivers the grain within a specified period (refer to Step 3 in Figure 1). If the agricultural company has a corresponding buyer for the grain, the SAFEX position is off-set by the agricultural company by entering into a corresponding SAFEX long position (refer to Step 4 in Figure 1). This is done in order to "close out" the SAFEX position. 


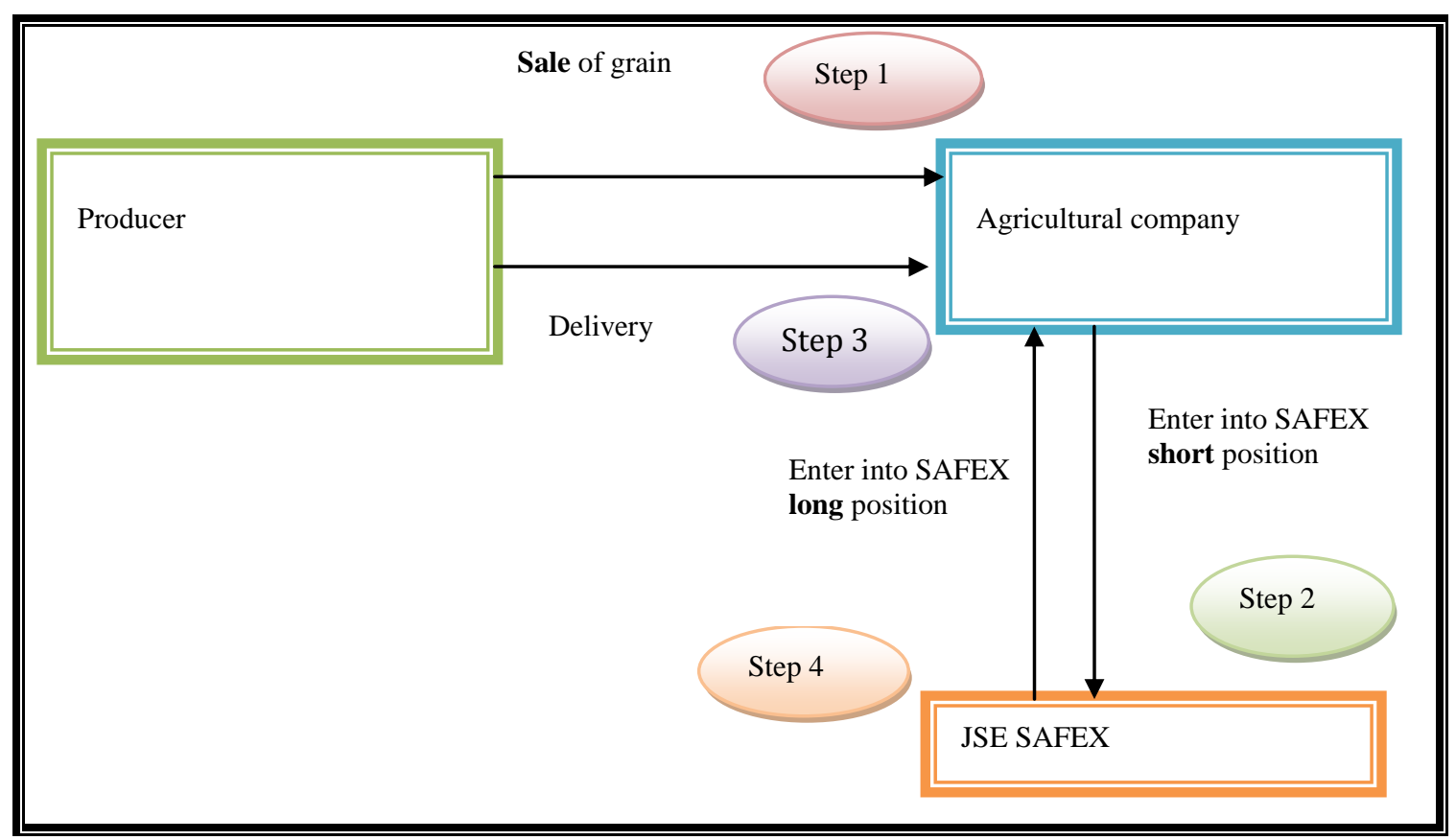

Figure 1: Pre-season fixed price contract (Source: Own research)

When the producer enters into a supply agreement with the agricultural company, the agricultural company should classify the supply contract (refer to Step 1 in Figure 1) as a derivative contract and mark-to-market (fair valued) it based on the SAFEX-based price in their accounting records. When the agricultural company enters into a SAFEX futures short position (refer to Step 2 in Figure 1), the derivative (futures contract) should immediately be recognised and marked-to-market based on the SAFEX-based price, in the accounting records of the agricultural company. The movement between the market prices of the derivative contracts is therefore off-set.

In respect of Best Practices, the following may be noted. The moment the producer is ready to physically deliver the grain, the agricultural company generally has a buyer, such as a processor, for the grain. When the producer delivers the grain (refer to Step 3 in Figure 1) to the agricultural company, which on-sells it to the processor, he/she enters into a corresponding SAFEX futures long position (refer to Step 4 in Figure 1). The result is that the grain is purchased at the ruling market price and sold to the processor at the same price, i.e. at the ruling market price. Inventory is not recognised in the accounting records of the agricultural company.

\section{Transaction type 2: Fixed-price purchase contract}

The second transaction type identified by the respondents is the fixed-price purchase contract. It was found that several versions of a fixed-price purchase contract were utilised by the respondents. The version described here refers to cash purchases (spot purchases) of a commodity at a SAFEX-based price and usually occurs after harvest time with no pre-season contract in place. The agricultural company purchases grain directly from a producer and considers whether it has a corresponding buyer for that grain. If the agricultural company has not yet found a corresponding buyer for that grain, it may enter into a short SAFEX position in order to protect itself against commodity price fluctuations until the grain is sold. At a later stage, when such grain is sold, the SAFEX short position is off-set by the agricultural company by entering into a corresponding SAFEX long position in order to "close out" the SAFEX position.

In respect of Best Practices, the following may be noted. The inventory balance in the accounting records of the agricultural company is not affected if a corresponding buyer exists for the purchased grain. When the agricultural company does not have a corresponding buyer, the agricultural company should increase inventory at the ruling SAFEX-based price and recognise a derivative contract that is fair valued until the grain is sold. When the 
grain is sold, the agricultural company should decrease inventory at the ruling SAFEX-based price and the profit or loss made between the SAFEX short and long position should be recorded in inventory.

\section{Transaction type 3: Pre-season minimum-price contract}

The third transaction type as per the respondents is the pre-season minimum-price contract. A minimum price contract is entered into before the planting season commences. Again, variations of the minimum price contract were in use by the respondents. One variation will be discussed here. This product affords the producer the opportunity to guarantee a minimum price without setting a fixed price for its commodity. A put option is purchased with a strike price equal to that of the minimum price. If the market price of the commodity or the contract increases, the put option becomes out-the-money, is worthless and is therefore not exercised. When the producer finally decides to sell at the SAFEX-based price, the entity enters into a corresponding short futures position on SAFEX in order to hedge themselves against future commodity price fluctuations. On the other hand, if the market price of the commodity decreases, the put option becomes 'in-the-money' and is therefore exercised, thereby ensuring that the minimum price is paid.

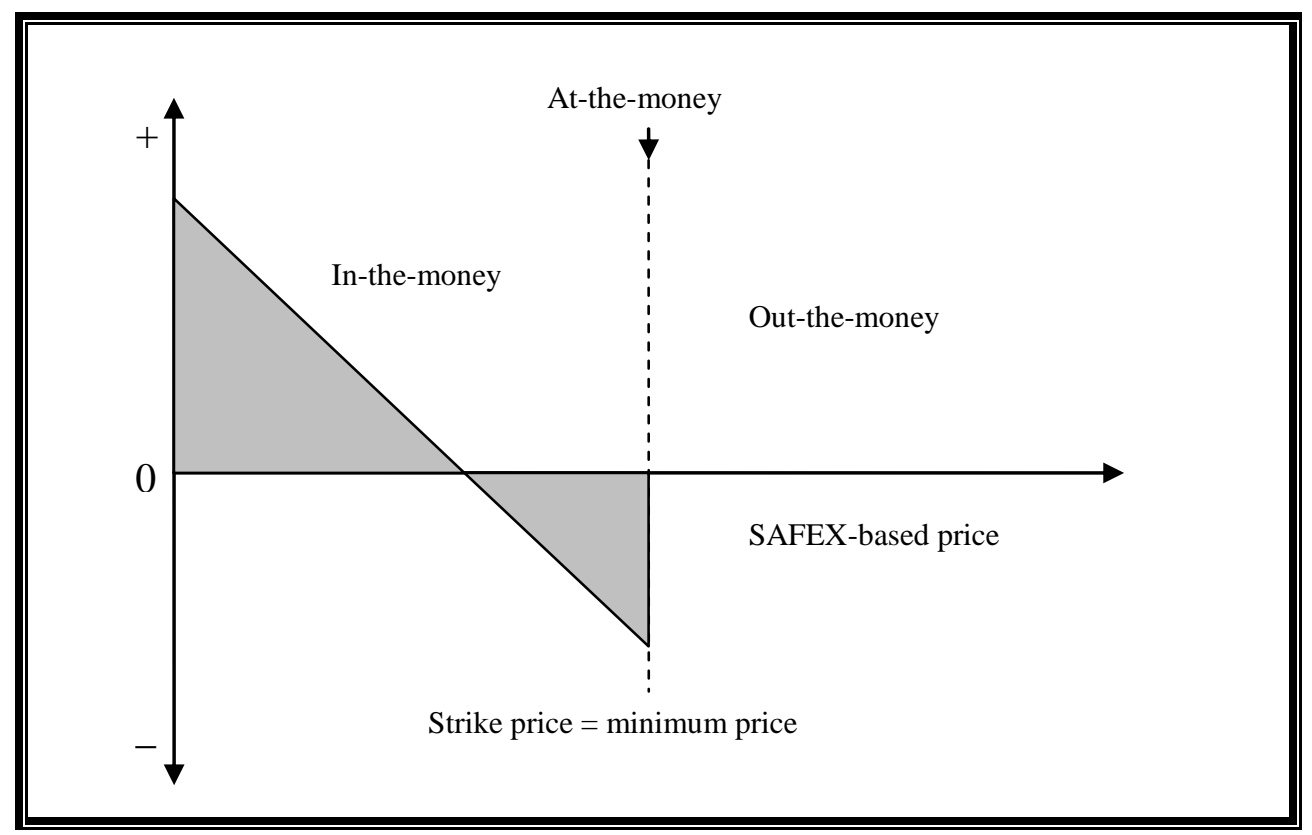

Figure 2: SAFEX put option

In respect of Best Practices, the following may be noted. The option contract is taken out on behalf of the producer by the agricultural company. The option premium payable on the put option is paid and recorded in the accounting records of the agricultural company. The option premium can either be charged to the producer's loan account immediately, or when the physical grain is delivered. SAFEX has a prescribed method of calculating the mark-to-market value of an option contract. The option contract is marked-to-market based on the SAFEX prescribed method. The question can be raised whether the profit or loss on the mark-to-market movement of the option contracts can be accounted for in the Statement of Comprehensive Income of the agricultural company as a profit or a loss. The option contract is taken out by the agricultural company on behalf of the producer and the risk and reward then lie with the agricultural company. In order to mitigate the risk for the agricultural company, there is a contract in place between the producer and the agricultural company transferring the risk from the agricultural company to the producer. The agricultural company therefore cannot reflect the fair value movement of the option contract as their profit or loss in the Statement of Comprehensive Income. The fair value movement on the option contracts taken out on behalf of the producer by an agricultural company should be transferred to the relevant producer's loan account. 


\section{Transaction type 4: Un-priced contract}

The fourth transaction type identified is a pre-season un-priced contract, which is similar to transaction type 1, except that the price, at which the commodity is purchased, either by the agricultural company or by the processor, is decided upon at a later stage. A specified period in which a producer could (and should) set the price based on the SAFEX price is agreed upon beforehand. The transaction type is translated to a pre-season fixed price contract the moment the producer decides to price his or her grain based on the SAFEX price.

In respect of Best Practices, the following may be noted. The agricultural company makes no accounting entries until the producer decides to set a price based on the SAFEX price. The transaction is then treated the same as a pre-season fixed price contract (transaction type 1). The accounting entries are therefore similar to the accounting entries of transaction type 1 .

\section{Transaction type 5: Delayed-price contract}

The fifth transaction type identified by the respondents is the delayed-price contract. This contract is similar to a pre-season un-priced contract between a producer and an agricultural company. A producer wants to sell the commodity, but is not yet willing to set a price at the time of the supply contract. However, at the time of the contract, the producer has a cash requirement. To accommodate the producer, a cash advance, based on a specific formula, may be provided by the agricultural company. Various formulas are in use to determine such a cash advance, including:

- $\quad$ A SAFEX-based price is set and an agreed upon percentage of the base price is paid as a cash advance.

- $\quad$ A SAFEX-based price is set and a put option is purchased with the same strike price as the SAFEX-based price. The put option premium is deducted from the strike price and the result is provided as an advance. The agricultural company enters into a long futures position for a future month and the producer is given the opportunity to price against that future month position. If the market price of the hedged commodity decreases, the entity is hedged and will receive its cash advance.

- An agricultural company will not offer this product if the grain price is high on the import parity differential level. This product will therefore only be offered if grain prices are aiming towards export parity level. The moment the producer sells its grain, the SAFEX price is determined and the entity enters into a short futures SAFEX position. The agricultural company also enters into another SAFEX position, but this time as a long position for a future month. The producer then has to price between the current period and the future month. The producer is then given a cash advance based on calculations performed by the entity generally based on a percentage differential from export parity level. As an additional risk cover, a top-up clause is written into the contract. If the grain price drops below export parity level, the producer is required to pay additional funds in order to top-up the funds the agricultural company holds as security.

In respect of Best Practices, the following may be noted. When the agricultural company provides the cash advance, an accounting entry is passed to increase the producer's loan account with the cash advance. When the producer decides to set a price, the accounting treatment of transaction type 1 is followed. If a put option is purchased, the accounting treatment of the pre-season minimum-price contract is followed.

\section{Contracts with processors}

Transaction type 6: Mill-door contract

The sixth transaction type identified is the mill-door contract, which can either be the case where a producer delivers grain to a miller, or a producer has already delivered to an agricultural company that in turn sells and delivers it to a miller.

In respect of Best Practices, the following may be noted. With reference to a processor, transaction type 1 (pre-season fixed-price contract) and transaction type 6 (mill-door contract) are treated the same and therefore the accounting treatment of a mill-door contract is similar to that of the accounting treatment of transaction type 1. 


\section{Transaction type 7: Un-priced delivery contract}

The seventh transaction type identified by the respondents is an un-priced delivery contract, which represents a contract with a buyer of a commodity with the option of pricing the commodity within a specified period. In respect of Best Practices, the accounting treatment of this contract is similar to transaction type 4 (unpriced contract).

\section{Transaction type 8: Priced delivery contract}

The eighth transaction type identified by the respondents is a priced delivery contract. This contract represents a contract with a buyer of a commodity with the buyer setting the price in advance. In respect of Best Practices, the accounting treatment of this contract is similar to transaction type 1 (pre-season fixed price contract).

\section{CONCLUDING DISCUSSION}

The twofold objectives defined earlier in the article were firstly to identify the primary transaction types in respect of commodity derivative contracts, and secondly to formulate a Best Practices standard methodology of accounting for these transaction types. Within the South African agricultural context, there were eight key transactions types identified, which can be classified into either contracts with producers or contracts with processors. Within the sector, there were often differing opinions around the interpretation of IAS 39 and its application. Even within the Big Four firms there were some disagreement on the interpretation and application of the accounting standard. However, in consideration of the feedback and responses of all the participants, it was possible to formulate Best Practice methodologies for the identified key transaction types.

The standard accounting treatment of transactions is imperative when these transactions are recorded in the financial records of a company to ensure comparability of financial statements. This article therefore recommended that standard Best Practices methodologies be applied when transactions that include commodity derivatives are recorded. When this methodology is followed, the financial statements should become more comparable leading to improved financial decision-making by the investors, analysts and financiers involved in the agricultural sector in South Africa.

\section{LIMITATIONS AND FUTURE RESEARCH}

The reader should take note that International Financial Reporting Standards, and then especially the area of financial instruments, are currently in a period of flux, with many developments being placed on the table. There are several reasons for this, including the convergence efforts between the Financial Accounting Standards Board (US) and the International Accounting Standards Board, and the complex nature of financial instruments that makes varying interpretations thereof a reality.

The purpose of this study was not to evaluate and comment on the accounting standards per se, but rather to consider the varying interpretations and applications of financial instruments within the South African agricultural sector.

Areas for further research might include i) expanding the study to include other sectors utilising derivative contracts and ii) an analysis of the disclosure of financial statements in the annual financial statements of entities to ensure a consistent disclosure.

\section{AUTHOR INFORMATION}

Dr Sanlie L Middelberg is currently a senior lecturer in the School of Accounting Sciences at the North-West University (South Africa), holds a PhD in Management Accountancy and is an Associate Chartered Management Accountant (ACMA). She has worked as Refining Accountant and Senior Internal Auditor at Total South Africa (Pty) Ltd for 5 years. She teaches in the Chartered Management Accountancy and Financial Accountancy programs. Her academic research output includes a number of peer-reviewed articles and conference presentations. Her current research focuses on the area of sustainable agriculture. E-mail: sanlie.middelberg@nwu.ac.za. Corresponding author. 
Professor Pieter W Buys is currently the Research Program Leader at the North-West University (South Africa) and holds two PhDs (Accountancy and Management Accountancy), two Masters Degrees (MComm and MBA), and he is also a US Certified Management Accountant (CMA). He has worked in the ERP and business consulting industry in Canada, the USA and South Africa for more than 15 years. He has published more than 28 articles in peer-reviewed and professional publications. His current research revolves around corporate social responsibility and corporate resilience. E-mail: pieter.buys@nwu.ac.za

\section{REFERENCES}

1. Burrell, G. \& Gibson, G. (1979). Sociological paradigms and organizational analysis: elements of the sociology of corporate life. London: Heinemann. $432 \mathrm{p}$.

2. Buys, P. (2008). In pursuit of a foundational accountancy philosophy. Koers, 73(3):489-508.

3. Cronje, C.J. (2010). A more subtle set of information in corporate annual reports for disadvantaged stakeholders. South African journal of economic and management sciences, 13(2):222-235.

4. Dunne, J. \& Edkins, B. (2008). The demand for food in South Africa. South African journal of economics, 76(1):104-117.

5. IASB see International Accounting Standards Board.

6. International Accounting Standards Board. (2008). International Financial Reporting Standards. Volume 1A. London: IASCF.

7. Lavin, C. (2010). Full text of Obama G20 speech: US won't "borrow and buy" the way to prosperity. http://blogs.forbes.com/beltway/2010/06/27/full-text-of-obama-g20-speech-us-wont-borrow-and-buy-theway-to-prosperity/ Date of access: 2 July 2010.

8. Maier, P., Homolka, J., Darabos, E., Tikasz, I.E., Peto, K. \& Nagy, A.S. (2009). Cultural and social accomplishments of agricultural companies as contributions to the development of rural areas. Applied studies in agribusiness and commerce, 3(3-4):21-23.

9. Nair, R.D. (2008). Food security in Africa: Challenges and Interventions. The IUP journal of agricultural economics, $\mathrm{V}(1): 61-76$.

10. Pickworth, E. (2009). Manuel: stricter rules needed. http://www.fin24.com/articles/default/display_article.aspx?Nav=ns\&ArticleID=1518-1786_2520487 Date of access: 22 May 2009.

11. PricewaterhouseCoopers. (2011). Agribusinesses: Benchmarking survey 2010. www.pwc.com/za Date of access: 4 August 2011.

12. PwC see PricewaterhouseCoopers.

13. Rossouw, J. (2010). Empirical results of the accounting policies chosen by South African listed companies. Meditari, 18(2):38-56.

14. Sundem, G.L. (2007). A note on the information perspective and the conceptual framework. (In Antle, R., Gjestal, F. \& Liang, P.J., ed. Essays in accounting theory in honour of Joel S. Demski. Springer: Science and Business Media. p. 285-292.)

15. Temkin, S. (2009). Accounting 'not to blame' for crisis. http://www.businessday.co.za/articles/topstories.aspx?ID=BD4A977140 Date of access: 24 April 2009.

16. Van Burick, N. (2008). Toegang tot finansiering bekyk. Landbouweekblad http://152.111.1.45/argief/berigte/landbouweekblad/2008/10/31/LB/70/02.html Date of access: 4 March 2009.

17. Williams, (2009). Rethinking decision usefulness. (A paper read at the $9^{\text {th }}$ Interdisciplinary Perspectives on Accounting Conference held in Innsbruck, Austria). 